\title{
11. PETROLOGY OF MIDDLE AMERICA TRENCH AND TRENCH SLOPE SANDS, GUERRERO MARGIN, MEXICO ${ }^{1}$
}

\author{
Steven B. Bachman, Department of Geological Sciences, Cornell University, Ithaca, New York \\ and \\ Jeremy K. Leggett, Department of Geology, Imperial College, London, United Kingdom
}

\section{INTRODUCTION}

The sandstone petrology of Leg 66 samples provides insights into changes through time in the geology of the source regions along the Guerrero portion of the Middle America continental margin. This in turn constrains possible models of the evolution of the Middle America Trench (e.g., de Czerna, 1971; Malfait and Dinkleman, 1972; Karig, 1974). Primarily medium-grained sands and sandstones, representing the widest variety available of trench/trench slope settings and ages, were analyzed in both light and heavy mineral studies. Standard techniques were used as much as possible in order to compare results from other margins and from ancient rocks.

\section{LIGHT MINERALS}

\section{METHODS}

Sand and lithified sandstone samples were prepared for analysis such that direct comparisons of their petrology are possible. Mediumgrained core samples were used exclusively. When graded beds were encountered, the medium-grain-sized intervals were sampled onboard. Sand samples 10 to $20 \mathrm{cc}$ were split in half, then washed in a stainless steel sieve to separate the fine fraction $(<0.063 \mathrm{~mm})$. The coarser fraction was then mounted in epoxy in cylindrical molds from which standard thin sections were cut. Thin sections were made directly from the lithified sandstones.

Standard petrographic techniques for point-counting (Dickinson, 1970; Graham et al., 1976) were used on both the sand and sandstone samples. A discrepancy between the two sampling methods occurs at this point; Dickinson's techniques for point-counting sandstones defines all grains smaller than $0.03 \mathrm{~mm}$ as matrix, whereas for the standard sieving technique, the defining fraction is $0.063 \mathrm{~mm}$. We used the standard techniques for each sample type because we feel it to be important for comparison with other data sets. Counts from sand and sandstone samples within several meters of each other gave almost identical results; thus the difference in grain size limits does not appear to affect the results appreciably. A total of 29 unlithified sands and 4 sandstones were counted at 160 power, using a $0.5-\mathrm{mm}$ spacing between points; 400 to 500 grains were counted in each thin section. Feldspars were identified, using the staining techniques of Bailey and Stevens (1960).

\section{Results}

The sands and sandstones are arkosic to subarkosic (Pettijohn et al., 1972) in composition (Fig. 1; Table 1). The mineralogic components of the samples have been grouped and plotted on triangular diagrams (Fig. 1), using the methods of Graham et al. (1976) and Dickin-

\footnotetext{
${ }^{1}$ Initial Reports of the Deep Sea Drilling Project, Volume 66.
}

son and Suczek (1979). The monocrystalline quartz has both undulatory ( $>5^{\circ}$ extinction) and nonundulatory extinction in different grains. Subgrain boundaries are developed in some grains. There is a large variety of polycrystalline quartz types; most samples have about equal percentages of finely crystalline ( $>5$ crystals/ grain) and coarsely crystalline ( $\leq 5$ crystals/grain) grains. Many of the finely crystalline quartz grains appear to be derived from rocks with a strain and/or metamorphic history: polyganized, bimodal (partial recrystallization of the larger set of grains), and tectonite (highly oriented crystals with elongate boundaries) types predominate. Plagioclase and potassium feldspar occur in near equal percentages (Qm-P-K plot, Fig. 1). Microcline is a common accessory in all the samples but is the predominate potassium feldspar in samples in the lower 100 meters of Site 493 on the upper slope. Only albite twins, which are locally bent or kinked, were observed in plagioclase crystals.

Rock fragments are primarily sedimentary, metamorphic, and plutonic in origin. Volcanic lithic fragments are uncommon. The sandstone and mudstone clasts look identical to the sediments deposited on the trench slope and probably represent material ripped up and redeposited on the slope and in the trench. Common carbonate shell fragments occur even in Quaternary sands deposited below the CCD. Apparently the megafossil fragments and some of the foram testes were transported from shallow water settings; the only possible in situ megafossil fragments are from the lower part of Site 493, where water depths were relatively shallow (see site chapter). Metamorphic rock fragments are schistose and gneissic. The dominant rock type, quartzmica schist containing both biotite and white mica, is similar to basement rocks cored at Site 489. Rare plutonic rock fragments contain quartz, potassium feldspar, plagioclase, and biotite.

The only lithified sandstones are of early Miocene age, near the base of Sites 489 and 493 . They are cemented by variably recrystallized micritic carbonate mud, with local extensive patches of recrystallized spar.

Alteration products in most of the sands were apparently inherited from source terrains. Feldspars vary from altered to unaltered within the same sample. However, in the lower cores of Sites 489,490 , and 493, carbonate has partially replaced several feldspar grains. In the lithified sandstones, it is apparent that this replacement is diagenetic rather than inherited. 


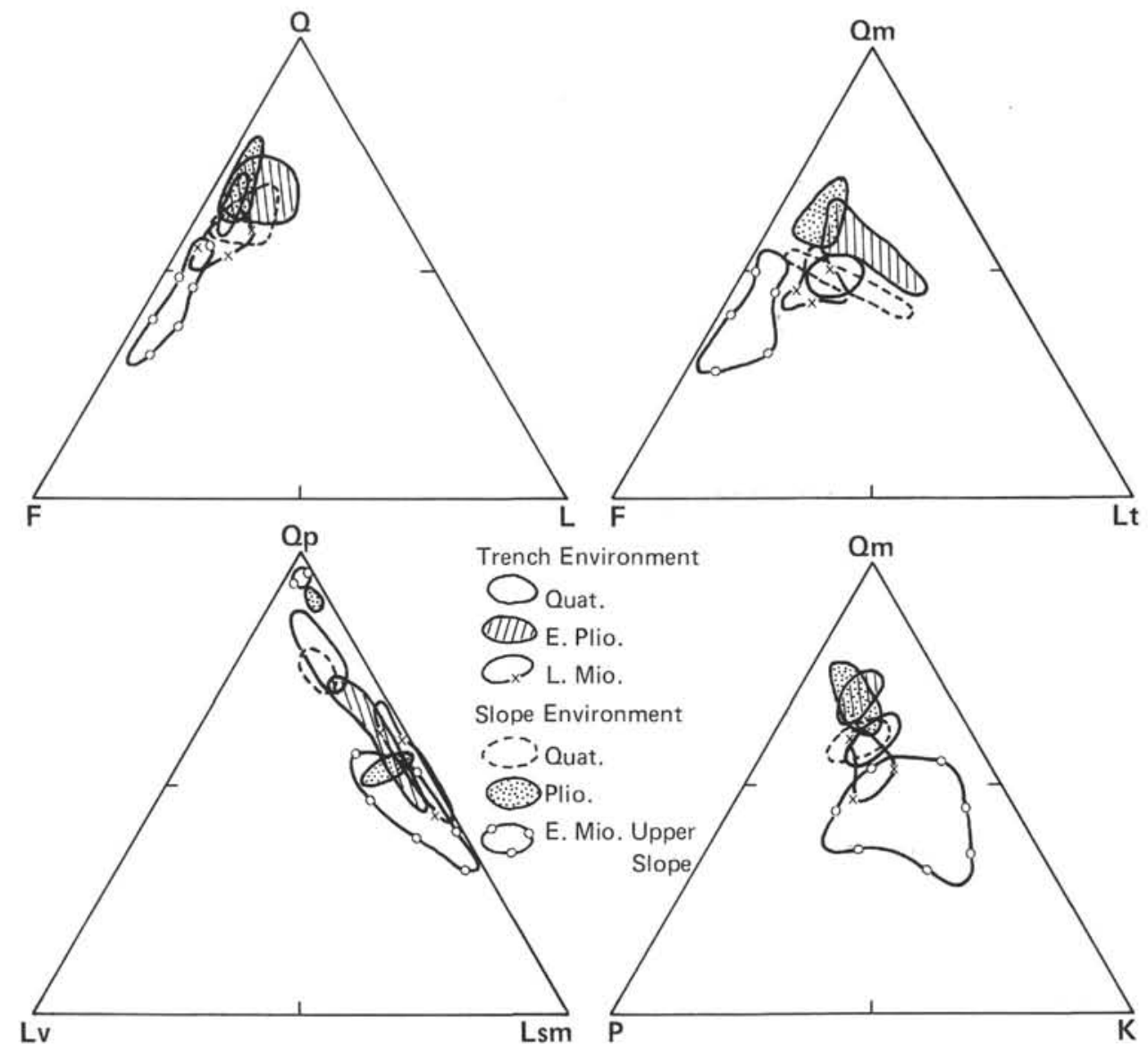

Figure 1. Triangular diagrams of detrital compositional modes of sands and sandstones from the Guerrero subduction complex. See Dickinson and Suczek (1979) for discussion of end members. Q = total quartz; $\mathrm{F}=$ total feldspar; $\mathrm{L}=$ total lithics; $\mathrm{Qm}=$ monocrystalline quartz; $\mathrm{Lt}=$ total lithics plus polycrystalline quartz; $\mathrm{Lv}=$ volcanic lithics; $\mathrm{Qp}=$ polycrystalline quartz; Lsm = sedimentary and metamorphic lithics; $\mathrm{P}=$ plagioclase; and $\mathrm{K}=$ potassium feldspar.)

The triangular diagrams in Figure 1 indicate the relative fractions of major components of sands of varying ages and depositional settings. Sediments older than Quaternary have been classified in a trench or slope setting according to their inferred depositional sites (see discussion in site chapters). The lower Miocene upper slope sediments generally have a higher percentage of feldspar (particularly potassium feldspar) and metamorphic rock fragments. The Pliocene sediments, both from trench and slope settings, have larger fractions of quartz, particularly monocrystalline quartz.

\section{HEAVY MINERALS}

\section{METHODS}

Table 2 contains grain size and sorting statistics for 18 samples from the fine-medium or coarser sands, dried and sieved to 0.300 $\mathrm{mm}, 0.210 \mathrm{~mm}, 0.125 \mathrm{~mm}, 0.063 \mathrm{~mm}, 0.053 \mathrm{~mm}$, and finer divisions. Heavy minerals were separated, using traditional techniques, with tetrabromoethane (specific gravity 2.97 ) as the separating medium.

A technique for heavy mineral characterization, using the electron microprobe with E.D.S. (energy-dispersive spectrometer), was employed to count grains. In many respects this method has advantages both in speed and accuracy over traditional methods. Different size fractions of the heavy mineral concentrates are mounted in shallow grooves cut across circular epoxy or Perspex discs; normally three dif- ferent size fractions are mounted on each disc. The mounted grains are then ground and polished on one side. With careful choice of grain concentration and monitoring of the thickness of the mount, a large enough number $(>200)$ of grains, if available in the original separate, will be exposed at the surface and may be examined using both reflected and transmitted light microscopy. In the microanalyzer the grains are moved sequentially under the electron beam, and an energydispersive spectrum is acquired. If a composite grain is suspected from prior optical inspection, the procedure is repeated several times to ensure reproducibility. If this is not reasonably good (bearing in mind, for example, compositional variations across garnet grains), the grain is rejected. In many cases the observer is able to identify the mineral, or at least classify it into a group in a time as short as ten seconds. In more difficult cases fully quantitative analyses may be required, and in these cases spectra may be stored on disc and processed later to be compared with mineral standards and analyses. On average, up to 100 grains per hour may be easily characterized.

A specific advantage of the technique, aside from speed and utility to the inexperienced petrographer, is that it can be used to subdivide groups of minerals according to their chemistry. For example, garnet species are relatively easy to identify, whereas it is very difficult using the traditional combination of optics and X-ray diffraction. Opaque minerals, not normally dealt with in heavy mineral studies, can be easily included in the analysis and indeed in this case have proved very useful.

Some minerals, however, cannot be distinguished by chemistry alone, particularly when short counting times and semi-quantitative analyses are used. The examples relevant to this study are the $\mathrm{Al}$ silicate polymorphs and certain clinopyroxenes and amphiboles ap- 
Table 1. Modal percentages of detrital components as percent volume, Leg 66 sands.

\begin{tabular}{|c|c|c|c|c|c|c|c|c|c|c|c|c|c|c|c|}
\hline Sample & $\mathrm{Qm}$ & Qp & $\mathrm{Qp} \leq 5$ & $Q p>5$ & Qpch & Qp bimodal & Qp polyg & Qp tect & $\mathrm{P}$ & $\mathrm{K}$ & Lv & Lsm & Carb. & Glauc. & Mafics \\
\hline $486-3-2,66-68$ & 43.0 & 13.4 & 5.9 & 7.5 & & & & & 14.9 & 12.2 & 0.5 & 2.9 & 5.1 & & 7.8 \\
\hline $486-3-6,58-60$ & 40.0 & 15.7 & 8.6 & 6.9 & & 0.2 & & & 18.4 & 12.0 & 1.7 & 2.7 & 2.7 & & 6.9 \\
\hline $486-5-2,40-42$ & 43.0 & 16.8 & 8.1 & 8.7 & 1.3 & 1.7 & & & 16.1 & 12.8 & 0.3 & 4.0 & 4.7 & & 2.3 \\
\hline $486 \mathrm{~A}-1-2,90-92$ & 41.4 & 8.0 & 4.0 & 4.0 & & 0.5 & & & 16.8 & 14.9 & 0.9 & 2.4 & 4.5 & & 11.1 \\
\hline $488-26-6,13-15$ & 50.2 & 4.9 & 3.5 & 1.4 & 0.3 & 0.3 & & & 25.1 & 11.1 & 0.7 & 0.7 & 2.4 & & 4.5 \\
\hline $488-35-1,88-90$ & 43.8 & 11.4 & 6.7 & 4.7 & & 1.3 & & & 17.0 & 12.2 & 0.9 & 13.3 & 0.2 & & 1.3 \\
\hline $488-35-1,130-132$ & 40.7 & 26.1 & 16.9 & 9.2 & & 3.2 & & & 11.9 & 9.9 & 3.2 & 6.7 & 0.7 & & 0.7 \\
\hline $488-45-1,61-63$ & 53.4 & 12.7 & 6.8 & 5.9 & & 1.2 & & & 17.8 & 12.9 & 1.0 & 0.7 & 0.5 & & 1.0 \\
\hline $488-45-2,42-44$ & 50.7 & 19.5 & 10.2 & 9.3 & 1.0 & 1.0 & & & 10.2 & 16.4 & 1.2 & 1.4 & 1.0 & & 0.2 \\
\hline $489 A-25-5,37-39$ & 47.0 & 3.2 & 1.4 & 1.8 & & & & & 19.2 & 25.8 & 0.7 & 1.8 & 0.5 & & 1.8 \\
\hline $490-5-7,9-11$ & 22.4 & 9.7 & 3.8 & 5.9 & 0.2 & & & 0.7 & 5.7 & 7.3 & 0.7 & 2.1 & tr. & 51.4 & 0.7 \\
\hline $490-45-1,70-72$ & 65.7 & 8.2 & 6.6 & 1.6 & & 0.2 & 1.0 & 0.2 & 16.6 & 2.9 & & 0.6 & 3.1 & & 2.9 \\
\hline $490-52-1,22-24$ & 54.6 & 3.2 & 3.2 & & & & & & 14.8 & 18.1 & & 2.3 & 3.0 & & 3.9 \\
\hline $491-11-2,89-91$ & 53.2 & 7.9 & 3.8 & 4.1 & 0.5 & 0.2 & & & 16.2 & 13.1 & 1.7 & 5.5 & 0.2 & 0.2 & 1.9 \\
\hline $491-50-6,61-64$ & 54.4 & 8.8 & 3.9 & 4.9 & 0.2 & 0.2 & & 0.2 & 18.1 & 11.7 & & 3.9 & 0.8 & & 2.3 \\
\hline $491-51-1,71-73$ & 53.6 & 18.0 & 10.8 & 7.2 & 1.0 & 2.4 & & & 11.8 & 7.7 & 1.7 & 4.1 & 1.4 & & 1.7 \\
\hline $491-51-1,140-150$ & 49.2 & 20.2 & 9.6 & 10.6 & & 0.8 & & & 7.6 & 8.6 & 1.3 & 9.6 & 1.8 & & 1.8 \\
\hline $491-53-1,35-39$ & 43.8 & 26.7 & 12.9 & 13.8 & 0.7 & 3.5 & 1.2 & & 9.7 & 7.4 & 2.5 & 5.9 & 3.2 & & 0.7 \\
\hline $491-58-3,122-124$ & 63.7 & 7.9 & 2.0 & 5.9 & 0.5 & 2.6 & & & 14.3 & 9.1 & 0.7 & 0.7 & 0.5 & & 0.5 \\
\hline $491-59-1,98-100$ & 46.3 & 12.4 & 6.7 & 5.7 & 0.2 & 0.2 & & & 14.9 & 6.9 & 1.2 & 13.6 & 1.7 & & 3.0 \\
\hline $492-27-4,141-143$ & 39.8 & 7.4 & 5.2 & 2.2 & & & & & 23.5 & 19.3 & 0.2 & 3.2 & 1.5 & & 5.2 \\
\hline $492-27-5,78-80$ & 54.0 & 9.4 & 5.4 & 4.0 & & 0.6 & 1.1 & & 19.8 & 12.6 & 0.4 & 2.3 & & & 1.5 \\
\hline $492-29-2,112-114$ & 48.1 & 7.8 & 3.7 & 4.1 & & 1.9 & & & 16.5 & 14.8 & & 10.0 & 1.2 & & 1.7 \\
\hline $492-29-3,126-128$ & 42.5 & 18.4 & 8.5 & 9.9 & & 1.8 & 1.6 & 0.2 & 15.8 & 15.6 & 0.6 & 3.4 & 3.4 & & 0.4 \\
\hline $492-30-3,18-20$ & 42.6 & 7.1 & 4.0 & 3.1 & 0.5 & 0.2 & & 0.2 & 17.5 & 17.7 & & 5.7 & 3.3 & & 6.1 \\
\hline $492 \mathrm{~B}-1-4,35-36$ & 44.0 & 14.1 & 5.4 & 8.6 & & 4.0 & & & 14.3 & 21.5 & 0.5 & 2.2 & 1.7 & & 1.7 \\
\hline $493-37-1,20-22$ & 31.6 & 6.3 & 3.6 & 2.6 & & & & & 33.6 & 17.8 & 0.3 & 4.9 & 1.0 & & 4.6 \\
\hline $493-51-1,127-130$ & 40.2 & 2.0 & 1.5 & 0.5 & & & & & 14.1 & 29.9 & & 4.0 & 8.1 & & 1.7 \\
\hline $493-52-1,124-126$ & 30.6 & 2.2 & 2.2 & & & & & & 4.1 & 22.3 & & & 39.6 & & 1.2 \\
\hline $493-52-2,99-101$ & 21.0 & 1.2 & 1.2 & & & & & & 9.7 & 23.3 & & & 44.4 & & 0.4 \\
\hline $493-53-1,10-11$ & 36.5 & 1.0 & 0.4 & 0.6 & & & & & 6.4 & 21.9 & & & 33.6 & & 0.6 \\
\hline $493-54-5,54-56$ & 19.7 & 0.9 & 0.9 & & & & & & 11.1 & 35.3 & 0.2 & 0.7 & 31.0 & & 0.9 \\
\hline $493-57, \mathrm{CC}$ & 49.3 & 2.2 & 2.2 & & & & & & 19.0 & 20.0 & & 4.2 & 4.7 & & 0.7 \\
\hline
\end{tabular}

Note: $\mathrm{Qm}=$ monocrystalline quartz; Qp = total polycrystalline quartz, including chert; Qp $\leq 5=$ polycrystalline quartz, 5 crystals or fewer; Qp > $5=$ polycrystalline quartz, more than 5 crystals; $Q p c h=$ chert; $Q p$ bimodal = bimodal polycrystalline quartz; $\mathrm{Qp}$ polyg = polyganized polycrystalline quartz; $\mathrm{Qp}$ tect = tectonite polycrystalline quartz; $\mathrm{P}=$ plagioclase; $\mathrm{K}=$ potassium feldspar; $\mathrm{Lv}=$ volcanic lithics; Lsm = sedimentary and metamorphic lithics; Carb. = carbonate; and Glauc. = glauconite.

Table 2. Total grain-size fraction and heavy mineral separate weights, Leg 66 sands.

\begin{tabular}{|c|c|c|c|c|c|c|c|c|c|c|c|c|c|c|c|c|c|}
\hline \multirow[b]{2}{*}{ Sample } & \multirow{2}{*}{$\begin{array}{l}\text { Wt. Sand } \\
\text { (g) }\end{array}$} & \multirow{2}{*}{$\begin{array}{l}\text { Wt. Clay } \\
\text { (g) }\end{array}$} & \multirow{2}{*}{$\begin{array}{c}\text { Total } \\
(\mathrm{g})\end{array}$} & \multicolumn{7}{|c|}{$\begin{array}{l}\text { Grain-Size Fraction } \\
\text { Weights }(\mathrm{g})\end{array}$} & \multicolumn{7}{|c|}{$\begin{array}{c}\text { Heavy Mineral } \\
\text { Separate Weights (g) }\end{array}$} \\
\hline & & & & 0.300 & 0.210 & 0.125 & 0.063 & 0.053 & Pan & Total & 0.300 & 0.210 & 0.125 & 0.063 & 0.053 & Pan & Total \\
\hline $468-3-2,68-72$ & 22.381 & 2.492 & 24.873 & 11.164 & 3.259 & 4.558 & 0.826 & 2.305 & 0.175 & 22.287 & 0.062 & 0.058 & 0.072 & 0.055 & 0.130 & 0.037 & 0.414 \\
\hline $486 \mathrm{~A}-5-2,36-40$ & 23.572 & 0.092 & 23.664 & 11.868 & 7.641 & 3.693 & 0.252 & 0.030 & 0.006 & 23.490 & 0.009 & 0.018 & 0.248 & 0.069 & 0.008 & 0.001 & 0.353 \\
\hline $488-35-1,126-130$ & 11.654 & 0.401 & 12.055 & 10.562 & 0.898 & 0.076 & 0.112 & & - & 11.648 & 0.053 & 0.019 & 0.011 & 0.015 & & & 0.098 \\
\hline $488-45-1,57-61$ & 19.310 & 0.395 & 19.705 & 4.892 & 11.612 & 2.519 & 0.160 & 0.049 & - & 19.232 & & 0.019 & 0.048 & 0.105 & & & \\
\hline $489 A-30-5,91-94$ & 10.010 & 4.945 & 14.955 & 0.058 & 0.134 & 0.852 & 5.954 & 1.156 & 1.778 & 9.932 & \multicolumn{7}{|c|}{ No data, sample contaminated with quartz } \\
\hline $490-18-4,130-133$ & 4.757 & 1.763 & 6.520 & 0.082 & 0.231 & 1.522 & 2.422 & 0.230 & 0.133 & 4.620 & & 0.004 & 0.004 & & & & \\
\hline $490-52-1,21-25$ & 14.819 & 1.178 & 15.997 & 0.702 & 0.869 & 7.783 & 0.147 & 4.907 & 0.234 & 14.642 & \multicolumn{7}{|c|}{ No data, sample contaminated with quartz } \\
\hline $491-19-1,111-115$ & 10.738 & 1.120 & 11.858 & 0.161 & 0.503 & 5.502 & 4.390 & 0.103 & 0.042 & 10.701 & & 0.002 & 0.006 & & & & \\
\hline $491-51-1,66-70$ & 10.982 & 1.035 & 12.017 & 5.540 & 1.129 & 2.572 & 1.492 & 0.069 & 0.029 & 10.831 & 0.012 & 0.014 & 0.007 & 0.087 & 0.020 & 0.001 & 0.141 \\
\hline $491-53-1,31-35$ & 19.599 & 2.255 & 21.854 & 15.200 & 1.662 & 1.897 & 1.549 & 0.102 & 0.125 & 19.535 & 0.061 & 0.026 & 0.018 & 0.137 & 0.021 & 0.009 & 0.272 \\
\hline $491-58-3,117-121$ & 20.965 & 3.845 & 24.810 & 10.990 & 3.270 & 4.216 & 2.208 & 0.117 & 0.052 & 20.853 & 0.019 & 0.042 & 0.006 & 0.038 & 0.018 & 0.014 & 0.137 \\
\hline $491-59-1,104-108$ & 5.544 & 11.806 & 17.350 & 0.618 & 0.219 & 0.909 & 3.333 & 0.289 & 0.123 & 5.491 & 0.001 & 0.001 & 0.002 & 0.052 & 0.017 & 0.026 & 0.099 \\
\hline $492-29-3,120-124$ & 16.206 & 9.230 & 25.436 & 8.604 & 1.253 & 1.298 & 3.178 & 0.569 & 0.279 & 15.181 & 0.030 & 0.009 & 0.037 & & & & \\
\hline $492-30-3,20-24$ & 11.012 & 10.726 & 21.738 & 3.082 & 2.716 & 2.910 & 2.071 & 0.122 & 0.101 & 11.002 & 0.016 & 0.011 & 0.020 & 0.083 & 0.017 & & \\
\hline $492 \mathrm{~B}-1-4,36-40$ & 15.180 & 1.820 & 17.000 & 10.365 & 1.429 & 1.565 & 1.513 & 0.079 & 0.128 & 15.079 & 0.046 & 0.028 & 0.019 & & & & \\
\hline $493-53-1,10-12$ & 12.246 & 2.846 & 15.092 & 7.596 & 1.482 & 1.354 & 1.297 & 0.166 & 0.224 & 12.119 & 0.001 & 0.014 & 0.002 & & 0.009 & 0.007 & 0.033 \\
\hline $493-54-5,53-56$ & 19.249 & 13.632 & 32.881 & 10.998 & 1.712 & 1.796 & 2.956 & 0.943 & 0.606 & 19.011 & 0.025 & 0.027 & 0.043 & 0.086 & 0.037 & 0.025 & 0.243 \\
\hline $493-58-1,3-5$ & 22.356 & 2.381 & 21.737 & 0.105 & 0.032 & 4.276 & 15.306 & 1.475 & 1.099 & 22.293 & 0.011 & & 0.022 & 0.109 & 0.059 & 0.040 & 0.231 \\
\hline
\end{tabular}

Note: Grain-size fractions are in $\mathrm{mm}$.

proximating tremolite-actinolite in composition. In some cases observation, using the limited optics of the microprobe, is sufficient. In others-for example, in assessing the relative abundance of sillimanite, kyanite, and andalusite-the sample has to be examined under the petrological microscope.

Because heavy mineral suites of different grain-size fractions from the same sample can vary, only one fraction $(0.125-0.210 \mathrm{~mm})$ was studied. A reconnaissance study of coarser and finer fractions shows trends similar to those commonly reported in heavy mineral studies: in particular, composite fragments are more common in the coarser grain sizes, and resistant accessory minerals, principally zircon, are more common in the finer fractions. Tourmaline, not observed in the analyzed fraction, occurs in several of the 0.063 to $0.125 \mathrm{~mm}$ fraction samples. Where possible, 100 nonmicaceous, nonopaque grains were counted. In some mounts, the abundance of micas or opaques, or paucity of grains in the original separate, meant that fewer were counted. When lower than 75 , data have been omitted from Figure 2 .

\section{Results}

Nonopaque minerals identified in Leg 66 samples are, in general order of abundance, amphiboles (predominantly hornblendes), micas (predominantly biotite), epidotes, garnets, Al-silicates, orthopyroxenes, and accessory minerals: sphene, apatite, zircon, ana- 
tase, and rutile. Of the opaque minerals, pyrite generally predominates over ilmenite and $\mathrm{Fe}$ oxides.

Hornblende dominates almost all the Quaternary and Pliocene samples analyzed but is less important in the Miocene samples (Fig. 2). Optical inspection shows the majority of grains to be of a blue-green variety, indicative of a high-grade metamorphic source (Petijohn, 1975); green-brown and brown (basaltic) varieties are also common, however. In Pliocene and Miocene samples, grain outlines are irregular (Fig. 3), suggesting that intrastratal solution may have taken place.

Epidotes and garnets, also indicative of metamorphic sources, are present in almost all the samples but are most common in the Miocene samples (Fig. 2). All members of the epidote group occur, but epidote predominates over clinozoisite and piemontite. These minerals are indicative of regionally metamorphosed rocks of the epidote-amphibolite facies.

In almost all samples the rare-earth-rich epidote, allanite, occurs. Particularly common in the Miocene samples (e.g., Sample 492-30-3, 20-24 cm), this mineral indicates a plutonic source as a characteristic accessory mineral in many granites, granodiorites, monzonites, syenites, and pegmatites.

Among the garnets, which in most cases are readily identifiable by microprobe, there is much compositional variation. Representatives of both the pyralspite and ugrandite series occur, with compositions centering around almandine and grossular, the former being marginally more common. The most common garnet in all samples analyzed is an almandine containing $\mathrm{Ca}$ and $\mathrm{Mn}$. The appearance of these elements in almandine, substituting for $\mathrm{Fe}$ and $\mathrm{Mg}$, is indicative of an increasing grade of regional metamorphism (Deer et al., 1966). Grossular is especially characteristic of both thermally and regionally metamorphosed impure calcareous rocks.

Mica flakes are almost entirely biotite, which may derive from both felsic igneous and high-rank metamorphic rocks. Optical examination shows some chlorites, but in all cases these have been altered from biotites. Biotite floods two Miocene samples and one Pliocene (Fig. 2; Table 3). At first glance, this observation merits suspicion, since micas often fail to settle out efficiently in tetrabromoethane. However, mica-rich light-mineral

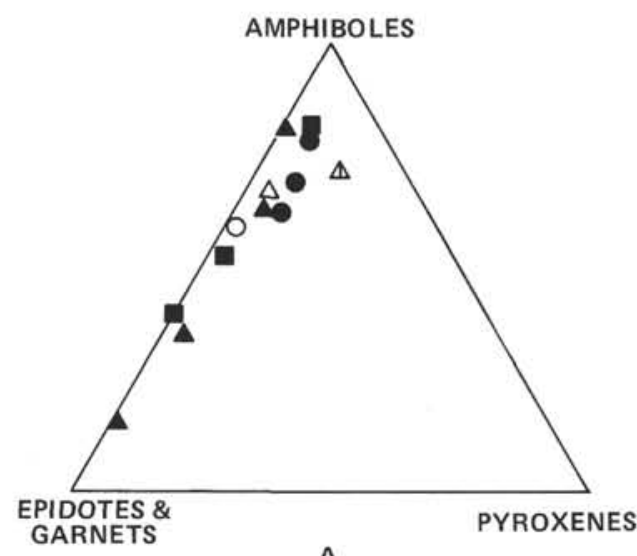

A

Slope Environment

O Quat.

$\triangle$ Plio.Slope Basin

$\triangle$ E. Plio.

$\square$ E. Mio. Upper Slope
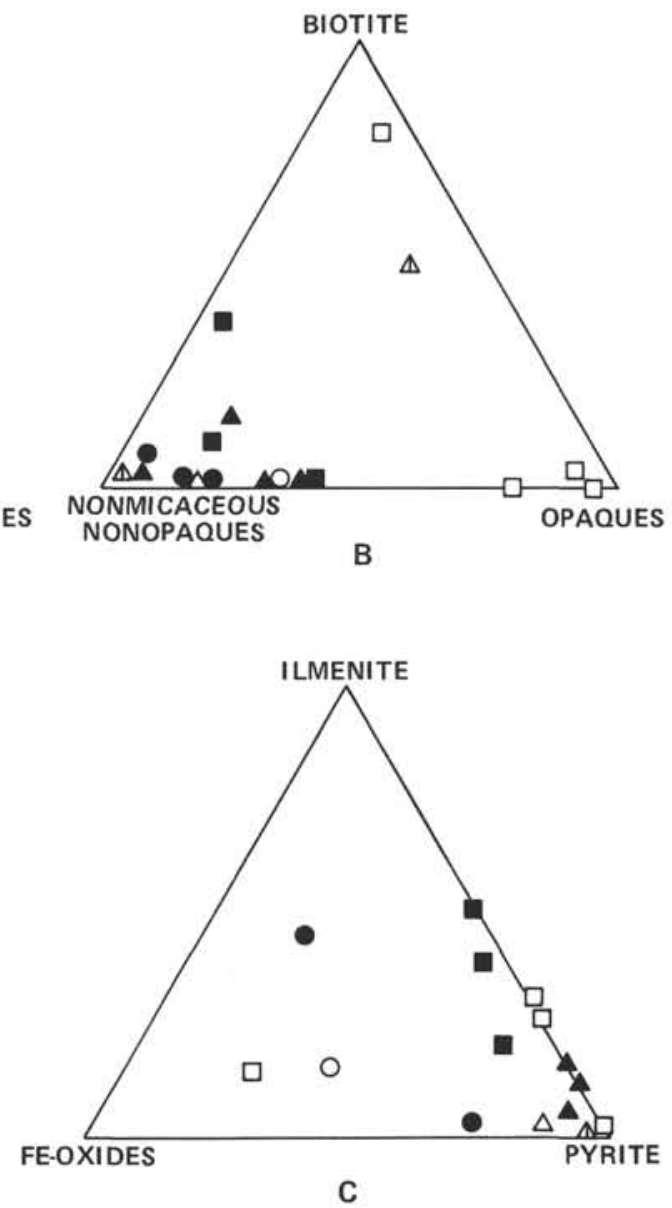

Figure 2. Triangular diagrams of heavy mineral components, Leg 66 sands. A. Nonmicaceous, nonopaque minerals. B. Micas, opaques, and nonmicaceous nonopaque minerals. C. opaques (grain counts with $<20$ opaques are excluded). 

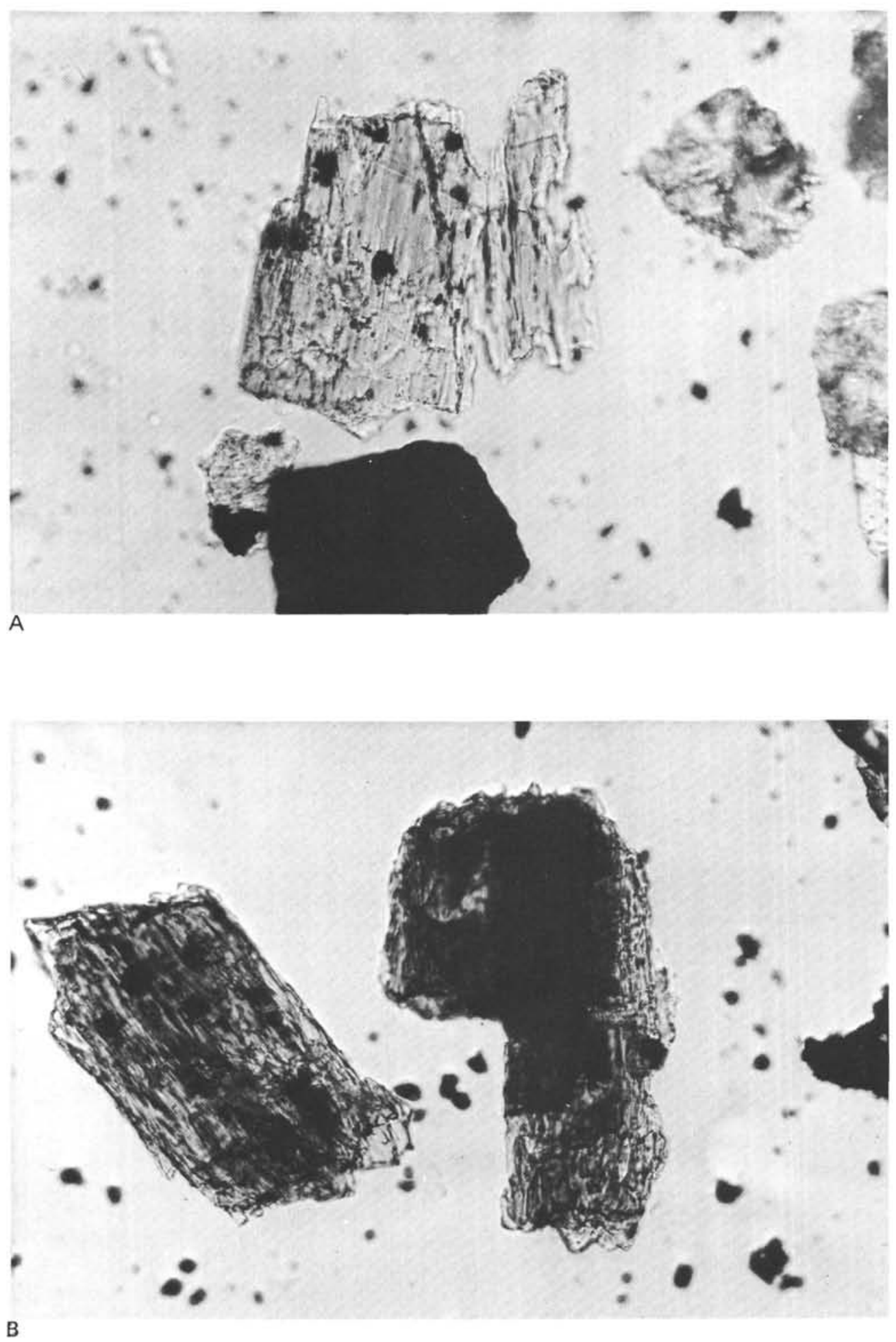

Figure 3. Etching of hornblende grains in Leg 66 sands. A. Sample 491-58-3,117-125 cm; grain is $0.125 \mathrm{~mm}$ across. B. Sample 489A-30-5, 91-94 cm; grains are approximately $0.1 \mathrm{~mm}$ long.

residues were not observed during separation, and it seems more likely that biotite was introduced in a pulsatory fashion from the source area.

Al-silicates, though not exhibiting any particular concentration trends, occur in samples of all ages (Table 3). Optical inspection shows them to be sillimanite predom- inating over kyanite and andalusite, indicating that a high-rank metamorphic component in the source terrain was probably unroofed between the early Miocene times and the present.

Orthopyroxenes, identified optically as hypersthene, are a minor but persistent component of the assem- 


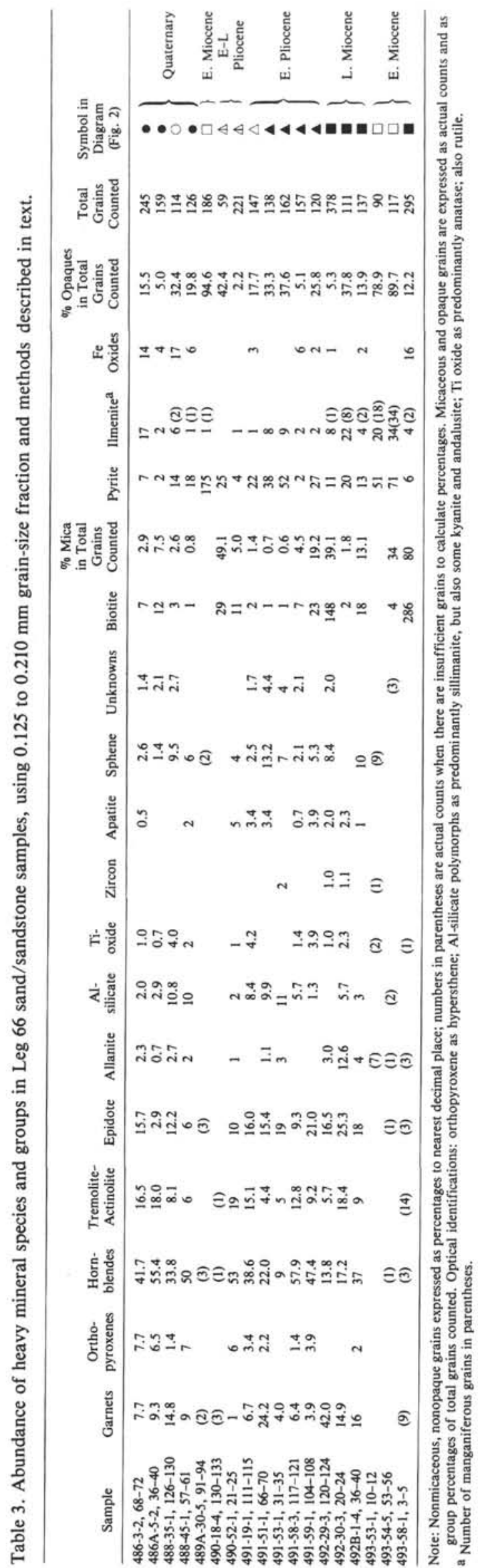

blages (Fig. 2; Table 3). Commonly derived from mafic igneous sources, it is likely that the Trans-Mexico volcanics are their source. Ross (1971) records concentrations of up to $60 \%$ hypersthene in heavy mineral suites (2.0-0.06 mm fraction) from the modern northern Middle America Trench. Our data indicate that volcanic sources may have been less important in ancient sands from the area farther south.

Of the accessory minerals, sphene, apatite, and zircon are generally held to indicate fels:c igneous sources and anatase and rutile mafic sources (Pettijohn, 1975). Although only sphene approaches a significant contribution to the heavy mineral suites, all except zircon are moderately persistent in occurrence, displaying no noticeable abundance trends. Zircon is rare, occurring in only minor proportions in Miocene samples (Table 3).

Interesting trends occur in the distribution of opaque minerals (Fig. 2). Their contribution to the total number of heavy mineral grains ranges between $5 \%$ and $95 \%$. In general the older the sand sample, the greater the proportion of opaque heavy minerals (Fig. 2). Of particular interest, Miocene shelf sands contain significantly more opaques than younger sands. The majority of these Miocene opaques are pyrite; oxides are virtually absent from early Miocene suites (only Sample 493-58-13, $5 \mathrm{~cm}$ contains them) but are only relatively common in Quaternary samples. The pyrite occurs as botryoidal aggregates, often having grown in foram tests. These observations testify to poorly oxygenated bottom waters in the outer shelf during the Miocene, a conclusion substantiated by the laminated Miocene sediments in cores from Sites 489 and 493 , cited in the site reports as evidence for deposition within an extensive oxygen minimum zone.

Much more ilmenite occurs in the samples from Site 493 than at any other site. Since ilmenite grains derive mainly from igenous sources and a concentration of felsic igneous-derived allanite is indicated at this site, it is probable that erosion of the underlying granodiorite contributed actively to the mineralogy of the overlying transgressive sands during the early Miocene. At Site 489 , a single sand sample of the same age possesses only one ilmenite grain and no allanite in a 186-grain count (Table 3); at this site the transgressive sands overlie metamorphic basement.

An interesting and as yet unexplained phenomenon is the concentration of $\mathrm{Mn}$ in ilmenites from Miocene samples. Many spectra from Miocene ilmenites show a small Mn peak: in some samples the majority of ilmenites have the Mn peak. In Sample 493-54-5, 53-56 $\mathrm{cm}$, all 34 ilmenite grains were manganiferous; in Sample 493-53-1, 10-12 cm, MnO concentrations in some cases exceed $10 \%$.

\section{DISCUSSION}

The composition of both the light and heavy mineral fractions of Guerrero sands indicates the dominance of metamorphic and plutonic rocks in the source area. Comparing the triangular diagrams in Figure 1 to the tectonic provenance fields of Dickinson and Suczek (1979) suggests an uplifted continental block prove- 
nance for Guerrero sands. In addition, quartz types and rock fragments show the importance of metamorphic and plutonic sources. The presence of blue-green hornblende, garnet, epidote, and sillimanite indicate a metamorphic source, whereas allanite and some of the accessory minerals indicate a plutonic source. Although there is some suggestion of a volcanic source (green-brown and brown hornblende, hypersthene), the low percentage of volcanic lithic fragments in sands of all ages indicates that there was not a significant volume of volcanics in the drainage system.

Both heavy and light mineral compositions vary somewhat with age in Guerrero sands. Four principal factors, reviewed by van Andel (1959), can modify the composition of heavy mineral suites. These are (1) weathering, which can occur both in the source and the depositional basin and can selectively move less stable phases such as pyroxenes and hornblende; (2) mechanical destruction of less resistant grains, usually by prolonged residence in high-energy depositional systems; (3) selective sorting of minerals according to size and density; and (4) chemical destruction of the less stable phases after deposition (intrastratal solution).

The high elevation of the western Mexico coast ranges ensures plentiful supplies of fresh rock to erode and reduce the probability of prolonged residence time of the sand between the source and site of deposition. We have commented on the importance of sorting, and attempted to circumvent the problem by choosing for analysis the grain-size fraction that we consider likely to give the most information on changes in geology of the Guerrero hinterland with time. Therefore the only factor that seems likely to modify our interpretations is intrastratal solution. This process clearly occurs, since older mafic minerals tend to be etched. Sands of similar age from DSDP sites in the Gulf of Alaska have been similarly affected (Scheidegger et al., 1973). However, because amphiboles occur widely despite the etching in older samples, their depletion in older sands may indicate a primary abundance trend in addition to chemical destruction after deposition.

The modern hinterland of the Leg 66 transect comprises the Rio Ometepec drainage basin, in which the outcrop is dominated by Precambrian and Paleozoic metamorphic rocks and felsic plutonics of Mesozoic and Cenozoic age; Cenozoic volcanic and volcaniclastic rocks are exposed farther inland. Since the early Miocene, metamorphic rocks, mostly of high grade, shed metamorphic polycrystalline quartz types, rock fragments, Al-silicates, and abundant garnets into Leg 66 sites. More garnet and epidotes and fewer amphiboles in older samples imply that the metamorphic source was of greatest importance in the Miocene, perhaps because fewer plutonics had been unroofed. On the other hand, concentrations of ilmenite, allanite, and microcline at Site 493 suggest that plutonic sources were important in the Miocene, although in the absence of additional data we cannot rule out a relatively local source from the underlying granodiorite. The reasons for the overall increase in feldspar in the lower Miocene portions of both upper slope Sites 489 and 493 are not clear; perhaps more local sources, decreased weathering and destruction of the feldspars during transportation.

Differences between Miocene and post-Miocene heavy mineral suites are most marked in the opaque grains. As already observed, however, the relative abundance of pyrite and virtual absence of oxides in the Miocene sands may best be explained in terms of lower dissolved oxygen contents in waters on the outer shelf.

The other significant petrologic change is the increase in quartz in the Pliocene samples from both trench and slope settings (Fig. 1), presumably reflecting transient changes in the type of rock exposed in the source area and/or changes in the sediment distribution system. Pliocene sea level changes were similar to those in the Quaternary and Miocene (Vail et al., 1977), so they are not the obvious cause of the transient changes. Increased uplift in local quartz-rich source areas could produce the petrologic variations; such arguments are difficult to evaluate. There was a relatively uniform rate of uplift in the accretionary zone itself, however, during this time (McMillen and Bachman, this volume).

Several models have been proposed to account for the apparent truncation of the Precambrian to Mesozoic metamorphic complexes (Kesler and Heath, 1970) at the southwest continental margin of Mexico. Two of these models suggest that either left lateral (de Czerna, 1971; Malfait and Dinkelman, 1972) or right lateral (Karig, 1974) transform movement has truncated the margin. The sandstone petrology of the Guerrero subduction complex constrains the timing of any such transform movement by recording changes in source terranes across a possible fault. For instance, sediments presently being shed from the Guatemala interior onto the slope and trench are volcanic lithic-rich (Enkeboll in prep.), in marked contrast to the petrology of Guerrero sands. Because the petrology of Leg 66 samples varies little with age or position on the margin, any transform translations of the accretionary zone must be restricted to areas with potential source rocks similar in composition to those now adjacent to the Guerrero margin. No petrologic evidence requires lateral displacement along the margin in the period from the early Miocene to Recent. Any possible movement appears to be restricted to within the metamorphic/plutonic provenance of the Mexican portion of the Middle America Trench, an area 300 to $400 \mathrm{~km}$ northwest and southeast of the location of the Leg 66 transect.

\section{ACKNOWLEDGMENT}

I would like to thank Dr. Teresa Jordan and Dr. Stephan Graham for reviewing the manuscript.

\section{REFERENCES}

Bailey, E. H., and Stevens, R. E., 1960. Selective staining of K-feldspar and plagioclase on rock slabs and thin sections. Am. Mineral., 45:1020-1026.

de Czerna, A., 1971. Precambrian sedimentation, tectonics and magmatism in Mexico. Geol. Rundsch., 60:1488-1511.

Deer, W. A., Howie, R. A., and Zussman, J., 1966. An Introduction to the Rock-forming Minerals: London (Longman).

Dickinson, W. R., 1970. Interpreting detrital modes of greywacke and arkose. J. Sediment. Petrol., 40:695-707. 
Dickinson, W. R., and Suczek, C. A., 1979. Plate tectonics and sandstone compositions. Am. Assoc. Pet. Geol. Bull., 63:2164-2182.

Graham, S. A., Ingersoll, R. V., and Dickinson, W. R., 1976. Common provenance for lithic grains in Carboniferous sandstones from Ouachita Mountains and Black Warrior Basin. J. Sediment. Petrol., 46:620-632.

Karig, D. E., 1974. Tectonic erosion at trenches. Earth Planet. Sci. Lett., 21:209-212.

Kesler, S. E., and Heath, S. A., 1970. Structural evidence for Precambrian rocks in the Xolapa complex, Guerrero, Mexico. Geol. Soc. Am. Abstracts with Programs, 2:287. (Abstract)

Malfait, B. T., and Dinkleman, M. G., 1972. Circum-Caribbean tectonic and igneous activity and the evolution of the Caribbean plate. Geol. Soc. Am. Bull., 83:251-272.

Pettijohn, F. J., 1975. Sedimentary Rocks (3rd ed.): New York (Harper \& Row).
Pettijohn, F. J., Potter, P. E., and Siever, R., 1972. Sand and Sandstones: New York (Springer-Verlag), p. 158.

Ross, D. A., 1971. Sediments of the northern Middle America Trench. Geol. Soc. Am. Bull., 82:303-322.

Scheidegger, K. F., Kulm, L. D., and Piper, D. J. W., 1973. Heavy mineralogy of unconsolidated sands in northeastern Pacific sediments: Leg 18, Deep Sea Drilling Project. In Kulm, L. D., von Huene, R., et al., Init. Repts. DSDP, 18: Washington (U.S. Govt. Printing Office), 877-887.

Vail, P. R., Mitchum, R. M., Jr., and Thompson, S., III, 1977. Seismic stratigraphy and global changes of sea level. In Payton, C. E. (Ed.), Seismic Stratigraphy-Applications to Hydrocarbon Exploration: Mem. Am. Assoc. Petrol. Geol., 26:63-97.

van Andel, Tj. H., 1959. Reflections on the interpretation of heavy mineral analyses. J. Sediment. Petrol., 29:153-163. 